\title{
Euro, Cost Benefit Or
}

\author{
Msc. Ejona Bardhi (Ph.D. in progress)
}

Lecturer at the Faculty of Law, University of Tirana

Email: ejona-87@hotmail.com

\section{Doi:10.5901/ajis.2014.v3n6p67}

\begin{abstract}
The first attempt to outline a path of economic and monetary union in three stages over a period of ten years, begins in 1970 with the report WERNER 1. However, this initial project did not come to fruition as a result of strong tensions that describes exchange currencies in international markets after the collapse of the Bretton Woods system in the early 70s, as well as the economic recession caused by the oil crisis in 1973. To cope with this situation fragile and unstable, nine member states of the EEC in 1979 created the European Monetary System (EMS), which basically was the mechanism of the exchange rate (MCR). This mechanism is provided for these 9 countries currencies, the determination of an exchange rate regime fixed, but adjustable. The idea of EMU will rejuvenate the Single European Act in 1986, which created a common market. This milestone also brought the conviction that the full benefits of the common market only if it can yield the participating countries will st use a single currency. In 1988, the European Council Delors Committee appointed to examine the possibilities and avenues for the creation of Economic and Monetary Union (EMU). A year later, the Delors Report will open the way to negotiations on the European Union Treaty, which created the European Union (EU) and thought the Treaty establishing the European Community. Otherwise known as the Maastricht Treaty, because the town where it was signed in February 1992, the Treaty of the European Union came into force on 1 November 1993. Road to EMU in Europe passed through three stages: The first phase (1990-1993) was characterized by the establishment of a common European market through the removal of all internal barriers to the free movement of persons, goods, capital and services within Europe. The second phase (1994-1998) began with the creation of the European Monetary Institute and focused mostly on the technical preparations for the European common currency, to avoid higher deficits and convergence of economic and monetary policies of the Member States (for sigruar price stability and sound public finances). The third phase began on January 1, 1999, with the irrevocable fixing of exchange rates, the transfer of powers of monetary policy to the European Central Bank (ECB) and the use of the euro as a single currency. On 1 January 2002, euro banknotes and coins were put into circulation in the participating countries and the end of February 2002 national banknotes and coins are no longer legal tender rejoiced. Today, after almost 12 years in circulation casting the single European currency and after the economic crisis of the euro area, which appeared in all its forms naturally arises: Euro has brought more costs or benefits? So, this paper aims to bring an analysis of the costs and benefits of the common currency Euro.
\end{abstract}

Keywords: Euro, cost, benefit, the European Union, the Economic Monetary Union

\section{Background of the Road to Economic and Monetary Union}

The path to achieve the economic and monetary union of European countries has been long and with lots of challenges. In 1957, at the Treaty of Rome, the six member countries did not predicted the possibility of unifying the economic and monetary field. Cause of this was the Bretton Woods system (where the European currencies were involved) signed in Washington on $27^{\text {th }}$ December 1945, which set a fixed exchange rate among currencies, converting the gold in "gold exchange standard" and American dollar as a reference currency. ${ }^{1}$

The creation of European Community of coal and steel, as a sectorial integration method, was the first stone in European building. The Treaty of Rome initially was created as the need of signing countries for an economic thrift. They did not stop only in creating mutual policies in solving the needs for coal and steel but the success in customs union and later the liberalization of agricultural market, brought qualitative changes in the economy of the six countries.

At the Hanover European Council, in 1988, it was elected a commission led by Jacques Delors with the aim of studying an extended Economic and Monetary Union, full integration of financial markets, full freedom of movement and transfer of capitals as well as achieving the realization of a unique currency. The commission proposed the creation of a

1 European Law - Iva Zajmi (2009) pg.220 
new monetary union through three phases: economic and monetary coordination, unique currency and creation of the Central European Bank as an autonomous institution and independent from the governments of member countries. The conclusions of this commission were examined by the Madrid European Council, in June of 1989 where was it decided the realization of the first phase of the proposal with the full liberalization of the eight members capital. The Treaty of Maastricht in 1992 forced the desire to have a unique European currency, which was strong and stable. In this way the Treaty of European Union was created, which is compounded by several provisions and protocols where the most noticed were the definition of the status of Central Banks European System (CBES), European Monetary Institute (EMI) and European Central Bank (ECB).

The European Union Treaty was realized in three phases,$^{2}$ the first one defined the creation of Euro. On $1^{\text {st }}$ January 1999 eleven member countries adopted Euro as mutual currency. The European Central Bank is now responsible for the monetary policies of the European Union. On 1st January 2002 the first notes of member countries are issued. The national currencies were withdrawn several months later.

The creation of Euro, with no doubt, is the most important economic phenomenon of the twentieth century. This was a huge logistic operation and its successful completion helped in the admission and trust of the Eurozone Citizens in the new currency. It came as a result of long process of collaboration and transformation of ideas and policies through European countries. Euro is the best possible European response in front of the massive globalization of world economicfinancial markets.

The unique financial market meant: freedom of capital circulation, transfer of the value from a country to another, services freedom, performed services from a country to another, financial services, facilitation of payments, freedom of opening small enterprises, founding of enterprises in the other country.

What do Eurozation and Dollarization mean?

The term dollarization is used when a foreign currency, not necessarily the dollar is adopted instead of the national currency, the dollarization may occur in several ways:

Non official without a legal approval (when the people of a country loses trust in its currency and prefers to use more and more the currency of another country for economic transactions)

Semi-official (the so-called bi-monetary system) where the foreign currency is announced legally acceptable but has a secondary role in relation to the national currency.

Official, when a state, renounces the emission and use of its currency and uses only the foreign currency.

The Eurozation can be adopted in four manners

- Unilateral eurozation

- Eurozation upon agreement

- Eurozation performed by a provisory administrate (such as UMNIK and Kosovo)

- Unilateral eurozation of an economy

When Euro started to be circulated it changed the monetary system in Europe having a huge effect on the nonmember countries of the Monetary Economic Union. The impact of Euro depends from the intensity of the commercial and financial relations of a country with the Eurozone, capital international market, exchange rate as well as the role of Euro as international currency.

Several countries attempted to profit from the created situation from the new European currency to urge their economic reforms and to accelerate the economic integration with western countries of European Union.

\section{Unique Advantages Euro Currency}

The prevailing opinion, in academic and political areas, is that the advantages of the Eurozation at list for a short-term period are deeply visible especially with the developing countries where the aspiration to enter in EU is big. Upon entering in the Monetary Union through using the same currency, the shocks with exchange and interest rates as source, are eliminated.

\subsection{Reduction of transactions costs}

The realities of these transition years, testified a citizens growing preference of using the European currency, which led at 
a partial Eurozation of the economy. The most touchable advantage of a partial eurozation is the reduction of the transactions costs. These costs, even though are truly losses for bank's balance sheets, impact the economy of a country that imports strongly and where every day more the restrictive fiscal policies push businesses toward a transparency of their financial capitals through legal channels.

\subsection{Reduction of exchange rate fluctuations}

A unique currency avoids the costs that the exchange rate fluctuations present for the economy of a country. A continuous fluctuation of the exchange rate of a currency bring instability of prices, insecurity at investors, high cost of investments as well as a growth of deficit of current account.

The Eurozation as an alternative, fundamentally, requires the interweaving of inflationary aggregates with the monetary ones as it is defined at the monetary politics regime of the European Central Bank. The monetary Unification eliminates pressures on exchange rates and as a consequence the achievement of prices stability is more credible. Being that a currency operating in a wide market is used, the exchange rate of this currency is not impacted by the internal market forces.

Since feudalism, it was the right of a state's ruler (signeur which generates the word seigniorage) to issue in circulation currencies. He could set a money value higher that the melted metal or stamp less metal with the same value. In this case the cost of coins productions was lower than the nominal value stamped and for this reason the difference was called "seigniorage". So seigniorage is the difference of the value between the typographic (paper and ink) expensed effectively to stamp and to issue the notes and coins, and the outer part value, the numeric written on the notes. He is the power of the circulation of the notes with a nominal value several times higher than the personal value they have, and as a consequence it is profited a profit from the sovereignty of the currency.

At the moment the European Central Bank that stamps the notes, buys goods using this note that cost very little to it, it gains unique purchase power. Not only this, the Central Bank that officially stamps notes with a ridiculous price (very low), sets the PASSIVE balance not the typographic cost really spent (paper and ink), but the numeric value written on notes and coins. Seigniorage in this way is turned into passive for the Bank, that is way it is not taxable and avoids the payment of taxes. Nowadays, with the paper money, its production cost is incomparable to it nominal value. As a consequence the incomes from the seigniorage are very high.

\section{The Albanian Economy and Euro}

The naturally arose question is: which are the costs and benefits the unilateral eurozation shall bring. Before we give a correct answer to this question, it is important to know in what scale it is de facto eurozated. Also we will treat the economic costs that seignorage has for our economy.

Albanian economy parameters.

Albania is one of the poorest countries in Europe although several politic and economic were adopted since $1992 \mathrm{~m}$ when the communist system of almost 50 years came to an end. The government for many years proceeded with a big integration of euro-Atlantic community. Albania signed the Agreement of Stability-Association with European Union in June 2006, a the first step towards the EU membership and submitted a full application for membership on April 2009 but it was refused. Currently EU accepted the request of Albania for the visas liberalization, to freely pass at the Schengen area countries, a right which was denied for several years to Albanians. In April 2009, Albania Achieved the full integration in NATO, signing a very important moment in its political development. The transport and energy infrastructure in Albania are in poor levels compared to the European Standards. The agricultural sector remains the bigger employment source. From the data it is clear that the world economic crises was reflected in Albania bringing decrease of basic indicators of the Albanian Economy. But in several reports of world economic prestigious institutions, Albania presents improvements in comparison to previous years. According to the repost of World Economic Forum on the competitiveness of economies, Albania is ranked at the $96^{\text {th }}$ position (2010) from the $108^{\text {th }}$ (2009) among 133 economies of several countries. The index of economy freedom ranks the Albanian economy the $53^{\text {rd }}$ in world, improving her with 7 positions from the last year. According to this report the economic freedom in Albania is comparable to the other countries in region such as Croatia and Macedonia. The report of World Bank "Doing Business 2012" shows that Albania made a positive progress by passing for the position 89 of the last year to 82 .

Seigniorage costs for Albania

If we speak for the conditions of Albania we will evaluate losses from the seigniorage as a consequence of the 
eurozation are in considerable values. On some studies on measuring the seigniorage in Albania it was concluded that its costs for the period 2002-2008 are in average 1,73 \% of the Gross Domestic Product (GDP). What is noticeable in this study is a decreasing trend of this voice in the incomes of the states budged in years. Measured according to the fiscal concept this income for Albania in the Studying period 2000-2008 is only $0.44 \%$ of GDP and constituted $1.92 \%$ of the fiscal incomes. Measured according to the concept of opportune costs, the incomes of seigniorage is nearly $1.85 \%$ of the GDP. From the above data we conclude that the cost of losing the incomes in Albania from seigniorage in case of a unilateral eurozation is insignificant.

Is there a real need for an eurozation of the economy?

The hope to participate in Europe is developing from more than two decades now. In 1991 when the transition process ended, Albania started from the most inappropriate conditions in all Central East Europe; it was completely isolated as it interrupted the relations with the Soviet Union and China, it had a centralized plan economy, severe and unreformed, despotism and the private property did not exist. In 198901992, Albania lost more than $40 \%$ of its GDP, but later the uninterrupted and stable economic growth, except 1997 when its GDB decreased with $7 \%$ made Albania one of the few countries in transition, that in 2000 overcame the level of 1989 (with three percent). Albania was a member of the World Trade Organization in September 2000; its regime of open trade is categorized at the first level from the 10 levels of indexes, defined by the International Monetary Fund. Inflation, initially in a three-digits classification, almost lowered to zero in 1990 and it has not moved more than 3-4\% since then. The domestic and outer imbalances are still present, but have obviously decreased. Systematic and structural changes have started. This mix of solid basis and with a relatively long time before the admission of European Union and even more the membership in European Monetary Union raises lots of questions. Firstly must Albania set a close relation to the Euro, for example, a set exchange rate or an instable scale of current exchange regime? Secondly, must Albania take unilateral actions toward a certain exchange rate with for Euro? This kind of "Eurozation" would take two shapes; a) official replacement and total of ALL with Euro or b) a currency board that would connect ALL in an unbreakable fixed equality. Which would be the cost of this benefits for Albania from such an action? Who would the gradual adjustment to EU standards with these costs and benefits would impact?? Which would be the consequences for developing negotiates with the EU.

The European Community as well as the European Central Bank, permitted the candidate countries to adopt any regime of exchange rate they choose, including a currency board, as it was approved from the admission in Bulgaria, Estonia and Lithuania. Eurozation seen in a narrow point of view, understood as replacement of the local currency with the euro, in contrary it was completely adjusted in a strict manner from the European Union until there were defined not only the convergences for entering but also the negotiated admission in the European Monetary Union: "Every unilateral adoption of the only currency in the framework of "eurozation" will be in contrary of the highlights of economic reasons of the European Monetary Union treaty, which predicts the current adoption of the Euro as a final point of the structured process of the convergence within a varied labor framework. For this reason, the unilateral eurozation will not be a possibility to avoid the steps predicted by the treaty on te adoption of euro. The unilateral eurozation is not the powers of the European Union authorities, but Albania as all candidate countries for admission, must have a favorable situation to negotiate its admission to eurozation and this is an alternative that should be considered. As we saw above, at the balance of the advantages and disadvantages, for Albania a unilateral eurozation is more convenient. It has de facto created its currency, the main mean for transactions within and outside the country. The real estate and buildings market for years now uses the euro currency for purchases. Albnian has the trade volume mainly to the countries where euro is the main currency for exchanges, it is surrounded by neighbor countries where almost all have as their official currency the euro. If economic parameters lead to a faster approach to Euro, the political will to loudly advance this alternative is missing. For the Bank of Albania, it will always be a taboo argument as it puts into risk its existence. The business community does not have any clear positioning for the unilateral eurosation of the Albanian economy. In order that the decision for unilateral eurozation is made, there is a need of clear strategy, well calculated steps and above all courage to break any fear or insecurity for this initiative.

\section{Conclusion}

Economic and Monetary Union (EMU), European Union scored another important step. Already businesses and consumers more easily compare prices and find the most convenient supplier to the Eurozone. In addition it has brought stability and monetary ekomonik across Europe, which contributes to sustainable economic growth and creating jobs. Likewise, the single currency ended disorders caused by unexpected fluctuations in the exchange rate of the previous national currencies. Using coins and banknotes euro, has become more simple trip across the Eurozone, as the prices of 
goods and services are easily comparable, but the payments are in the same currency in all its countries. Over in Euro within the Eurozone were eliminated transaction costs and risks associated with foreign exchange rate. In the past, such factors impede competition between countries, while its growth promotes a more efficient use of economic resources. The single currency investment decisions are significantly simplified, because of exchange rate fluctuations do not affect the income from investments made in different countries of the euro area.

Adoption of the common currency is an important step toward the integration of the euro area financial markets and will continue to affect the structure of the economy of this area. Different levels of integration can be seen in all segments of the financial system:

- The Eurozone interbank monetary market is fully integrated

- The bond market denominated in euros, has a good level of integration, depth and liquidity, and provides numerous opportunities for choices in terms of investment and financing

- The stock market Eurozone increasingly seen as a common market.

The melting and absorption activity in the banking sector in the euro area has increased at the national as well as cross-border level.

The crisis that European Union is passing is seen as a challenge from the member states, a challenge which is believed to pass by staying united and by helping economically weaker states and by returning the stability in economy. Anyway the existence of a mutual currency such as euro avoids the costs caused by the exchange rate for the economy of a country, increases the possibility of investments, brings freedom of capital circulation etc., leading to increase of benefits of a country.

\section{Bibliography}

European Union, the idea of integration, identity, future-Paskal Milo, "albPAPER" (2002)

European common market- Iva Zajmi (2009)

European Law - Iva Zajmi (2009)

Official Journal of the European Union 2008-Consolidated version of the Treaty on EU

Official Journal of the European Union 2003, opinion of the ECB on the draft treaty on establishing a constitution for Europe

\section{Web pages}

http://ec.europa.eu/enlargement/enlargement_process/accession_process/how_does_a_country_join_the_eu/sap/thessaloniki_sumit_en .htm

http://www.bankofalbania.org.web/Materiale_diskutimi_Seria_2009_5782_1.php?evn=srm\&kc=0,22,12,11,0\&rpp=1\&rp=10\&bsnid=bsnid \&fkid=fkid\&nsfkid=nsfkid\&msv=MSparams\&

http://www.case.com.pl/dyn/servFile.php?plik_id=70709 
